\title{
Pandemic and Virtual Learning: The Fourth Era in the Growth of English as a Global Language
}

\author{
Ms. Nandhini R \\ Assistant Professor of English \\ South Indian Vanniar Educational Trust College \\ Chennai, Tamil Nadu, India \\ nandhini@sivet.in
}

Dr.T.V.S.Padmaja

Principal and Head, Dept. of English

Valliammal College for Women

Chennai, Tamil Nadu, India

Abstract

The status of English language among all other languages is always a topic of interest for many centuries. It appears that no other language ever created a colossal impact on other cultures, languages and world history. This paper will investigate the question of what defines a language as a global language and what factors are the factors that determine the status and the present state of English during the Covid 19 crisis.

Keywords: English- Global Language History- Three Eras of English- Digital Technology. Introduction:

The status of English language among all other languages is always a topic of interest for many centuries. Statements like "English is today a truly global language" (Rubdy 2006: 5) affirms that English Language indeed has obtained a global status. "A language achieves a genuinely global status when it develops a special role that is recognized in every country" 
(Crystal 2003b: 3). However, Crystal admits that a 'special role' can mean a lot. In any circumstance, it can be said that the population living in an environment in which the English language is routinely in evidence, publicly accessible in varying degrees, and part of the nation's recent or present identity (Crystal 2003b: 66). It appears that no other language ever created a colossal impact on other cultures, languages and world history. This paper will trace the three eras through which English language established itself as a global language and the factors that determine the status of English during the Covid 19 crisis paving way for its fourth era.

Tracing the Three Eras of English as a Global Language:

The English language was considered as just another language till the nineteenth century, later the language started gaining momentum and it had many speakers from across the world. The reason for this drastic change is discussed in the following paragraphs.

In today's world some sixty percent of the population is multi lingual. In the contemporary world as well as in history, bilingualism and multilingualism is a norm due to commerce. The dual languages were spoken by people based on the geographical region they lived in. If we introspect the current situation, one could witness that English is the most used foreign language. Before the 14th century Latin was the dominant language in the European world. The language was considered noble that the grammar texts of English Language was first written in Latin. Due to some political changes in Europe Latin was slowly replaced by French. Though French language gained prominence during this period, it was not as influential as Latin. During the 19th century English language started establishing itself as the language of the world. English has undoubtedly become the global language. It has achieved such a pivotal role today that no other language is likely to take its position in the foreseeable future. Not only does it have a widespread profile ranging from international politics, science and technology, press, advertising, education, motion pictures, internet and communications and much more. it, also has become the language of at least a quarter of the world's population. The number of people 
who speak English either as a second or a foreign language is three times more compared to the number of people who speak it as a first language.

The spread of English Language can be recounted in three major eras of its development. The imperial expansion of Britain is the first era, during which most of the European superpowers spread their influence over different parts of the world. During this period, English found the phenomenal expansion of the British Empire as the most convenient method to reach different corners of the world. The other countries that expanded their global influence during this period, but were not able to match the reach of Britain were Portugal, Spain and France.

Most of us associate the history of English with the British colonizing major parts of the world. However, it is way back as 1759 , which we can call the first era, that the Christian Missionaries with great zeal and enthusiasm initiated the process of establishing English-medium schools across the world. Their primary desire was to open the doors of Christian faith to the natives so that they could come out of the darkness of ignorance and superstition. Although they emphasised the importance of native languages in early education and the learning of English as something expected to only increase the scope of clerical jobs, English-medium schools soon became the preferred choice over the vernacular schools. The majority started to believe in the superiority of English language and Literature.

The second era began during the post-colonial period, where in many countries national leaders were left with circumstances in which elimination of English from the Indian soil could not be considered a possibility. English language strengthened its roots in almost all spheres: journalism, judiciary, education, new knowledge and became strongly entrenched. Although the Governments in countries like India, Srilanka, Africa etc made several attempts to give equal importance to mother tongues they could not stop the rapid growth of the English Language.

The third era is the recent period of globalization. Globalization is an economic process that promotes market-driven economy. It has had its impact on the stronger and faster spread of 
English, even in those countries that strongly resisted its influence over the years such as France and Germany. The concept of one world was merely a utopia until the breath-taking revolutions in modern science and technology, especially in the field of communication. In the olden days the contact between various countries was for ruling purposes. The powerful countries always attacked the weaker ones and brought them under their control. This scenario changed after the arrival of the internet. The internet fastened the process of Globalisation and it made the entire world a 'Global Village'.

Today no country in the world can have the privilege of cutting ties with the world. In order to develop, every country should join the global network. People have started to realise that resistance is of no use and economic growth can be attainted only by joining hands in the global market. Many advocates of globalization also affirm that, Globalisation is essential for meaningful growth and development.

The Fourth Era of English Language:

English Language has entered into its fourth era as a global language during the covid-19 pandemic. Every other era led to English as a global language due to drastic change in one particular field like for instance the industries, trade, colonisation and this time the giant leap was made possible due to the education sector. Since many countries have imposed a lockdown on movement, and many schools and colleges have subsequently closed their doors, vast numbers of previously tech-shy teachers and students are having to learn very quickly how to teach using online resources. This could be attained by delivering lessons in the virtual mode or providing online study material for students, which may be new modes of teaching and learning for many. Since the rise of the internet in the 1990s, teaching and learning was moving forward in the digital world at a snail's pace. Initially there was very little interest to embrace digital ways of gaining knowledge, meaning that many teachers and learners feel that they have been poorly prepared to use technology in their education system. Consequently, many were resistant to the incorporation 
of digital technology in education, which has already become part and parcel of other sectors of our lives. There are a number of reasons for the teachers' hesitation in introducing technology into Education. The three most common reasons are:

(i) Technology hinders the holistic development of students.

(ii) Technology is distracting- many institutions had banned technological gadgets like mobile phones as they were considered highly distracting the students.

(iii) Technology is isolating - learner interaction is limited, and dissimilar to the kind of ways that they will be required to use language in the real world.

With the coming of the pandemic, the situation became vice-versa. In many situations, technology is the only mode of interaction. If not for technology the field of education would have regressed back to quarter of a century. Now, education across the globe has started functioning in the online mode. Because of this, many teachers and students have got an opportunity to explore international platforms through webinars, virtual conferences, student exchange programmes and MOOCs. The properly channelised virtual- learning programmes help the education sector open a plethora of opportunities for teachers as well as the learners. This has paved way for the learners to have interactions with their peer groups from various continents. This kind of channelised interactions under the supervision of the teachers is improving the proficiency of the learners, at the same time it is leading to the growth of the English Language as it increases the number and efficiency of the speakers.

Teaching is not longer a static discipline when it once centred around the teachers alone, where teachers were mediators between the text and the students. But today English teachers are better conceptualised and they create space beyond the text books and classrooms for the students to grow. This space that is created has indirectly become the reason for the growth of the language. This growth does not only help learners within their classrooms but also become skilled 
stake holders of education who can have access to global networking - making them globally professional and simultaneously it nurtures English Language attain a phenomenal stage. Conclusion:

The setbacks may be numerous due to the interference of technology in the Education Sector. Every dark period has a silver lining to it, similarly when this pandemic is all over, we could witness online learning become an integral part of the education sector in major parts of the world making English stronger as a Global Language making it flourish in its fourth era. 


\section{References}

"Bill Bryson Collected news and commentary" The New York Times.

Clark, T. (2018). Key Challenges and Pedagogical Implications: International Teacher

Perspectives. Cambridge Assessment English Internal Report.

Crystal, David (1997). English as a Global Language. Cambridge: Cambridge University Press. https://www.grin.com/document/113862

https://www.hausarbeiten.de/document/113862 